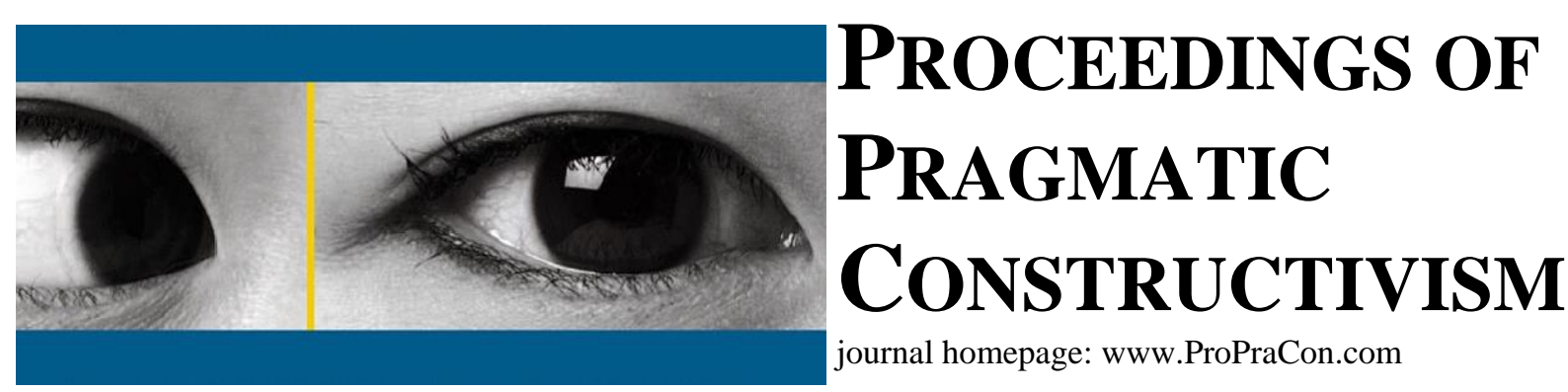

\title{
Roles of accounting in New Service Development within Servitization - The viewpoint of pragmatic constructivism
}

\author{
Teemu Laine \\ Associate Professor \\ Tampere University of Technology; Cost Management Center \\ PO Box 541, 33101 Tampere, Finland; teemu.j.laine@tut.fi \\ Lino Cinquini \\ Professor of Management Accounting \\ Scuola Superiore Sant'Anna; Institute of Management \\ Piazza Martiri della Libertà, 24; 56127 Pisa; Italy; l.cinquini@sssup.it \\ Petri Suomala \\ Professor \\ Tampere University of Technology; Industrial Management \\ PO Box 541, 33101 Tampere, Finland; petri.suomala@tut.fi \\ Andrea Tenucci \\ Assistant Professor of Management Accounting \\ Scuola Superiore Sant'Anna; Institute of Management \\ Piazza Martiri della Libertà, 24; 56127 Pisa; Italy; a.tenucci@sssup.it
}

\begin{abstract}
Motivation \& purpose: While acknowledging the importance of servitization, we are concerned about the absence in the academic literature of the roles of accounting in such a transformation (Laine et al. 2012a). We employ pragmatic constructivism (Norreklit et al. 2010) to explore the current and potential roles of accounting in new realities stemming from servitization.

Servitization literature in general has not succeeded in providing tools and techniques to support companies under servitization (Baines et al. 2009). Servitization processes typically aim at developing product offerings and customer relationships of the focal companies (Penttinen \& Palmer 2007), and thus constitutes a major change at the levels of the servitizing companies, the business units and a number of individuals within. Pragmatic constructivism provides a sound basis for analyzing socially constructed realities, or realities under construction, and is therefore a potential viewpoint for better understanding also servitization processes. More particularly, the employment of facts, possibilities, values and communication as central concepts of pragmatic constructivism could help in outlining the potential roles of accounting in supporting the servitization processes, as it is already been used in the context of accounting supporting strategic level organizational changes (Mitchell et al. 2013). We propose pragmatic constructivism to be used in examining in-depth qualitative data, where it can be a potential viewpoint to provide new knowledge about the new realities of servitization and the roles of accounting enactment from different perspectives.

Methodology: The data of the paper comprises a literature review and a survey that constitute the basis for research implications. The review focuses on the identified roles of accounting in servitization within selected thirtythree (33) scholarly journals on service, servitization or accounting. Empirically, the current servitization initiatives as well as the current and potential roles of accounting in servitization are explored within the sample of 451 Finnish and Italian machinery manufacturers.
\end{abstract}


The line of the argument of the paper is the following. First, the knowledge gap of the supportive tools and techniques for servitization is identified and the inquiry is further specified into the roles accounting in supporting servitization. Second, a literature review is conducted to confirm the aforementioned research gap and to preliminary explore the roles of accounting in the new realities resulting from the servitization processes. Third, the survey data is used and reflected upon the review results to better characterize the current servitization initiatives and to examine the current and potential roles of accounting in supporting those initiatives, especially within new offering development. Fourth, pragmatic constructivism is used as a framework to describe the requirements set for accounting by servitization and to outline the unused potential of accounting in supporting servitization. Finally, the paper discusses implications for managing servitization initiatives and proposes an agenda for further research, with an emphasis on in-depth case studies on companies under servitization.

Findings: The literature review confirmed the existence of the research gap regarding the roles of accounting in supporting servitization, more particularly regarding New Service Development (NSD) activities. In fact, only a few papers even address explicitly the topic of planning and controlling the servitization. The papers found in the survey emphasized e.g., the importance of understanding values and related business possibilities in the customers' business (Laine et al. 2012b), identifying the unwanted losses in the existing reality (Shulver 2005) from the viewpoint of the requirements of the new business possibilities, and examining the requirements of measuring the facts and possibilities related to the customer experience (Palmer 2010) so far neglected by many manufacturers. These all set requirements for accounting in servitization.

The preliminary survey results reinforce the importance of servitization among machinery manufacturers and also reveal differences in the servitization processes in terms of scope and content and, more importantly, from the viewpoints of different actors, such as general managers, service managers, R\&D managers and business controllers. Although many companies systematically manage the offering development for servitization, accounting does not succeed in supporting creativity and succeeds only to some extent in supporting the overall servitization strategy. This might be partly due to the fact that accounting tools available are not widely used in this context.

Pragmatic constructivism is thus used in outlining the requirements, current status and future potential for accounting in supporting servitization processes. Besides controlling the servitization initiative, identifying new business facts, possibilities and their value could help different actors in defining and justifying the initiative (Laine et al. 2012a). Moreover, as servitization yields a new (socially constructed) reality for the managers, the information needs (accounting objects) and the roles given for accounting require re-definition. This may be done value creation with (and at) the customers, with renewed costing and pricing tools (see e.g., Barontini et al. 2013).

Implications: To enhance the servitization literature, the paper implies an agenda for further research that should include i) defining and positioning the servitization initiatives from multiple actors' perspectives to outline the requirements set for accounting, ii) examining the current and potential roles of accounting within servitization and iii) focusing particularly on accounting development in this context. More generally, the agenda for further research holds potential in shedding light on the roles of accounting in the strategic change context (Naranjo-Gil \& Hartmann 2007, Cinquini \& Tenucci 2010, Mitchell et al. 2013), where the realities of the key actors are significantly redefined.

Originality/value: The paper responses to a relevant research gap of supporting servitization in different ways with accounting tools and techniques. More particularly, the paper provides a novel perspective to its topic, by approaching the new realities and related accounting implications stemming from servitization, as (potentially) interpreted by the key actors.

Keywords: Roles of accounting, Servitization, Pragmatic Constructivism. 


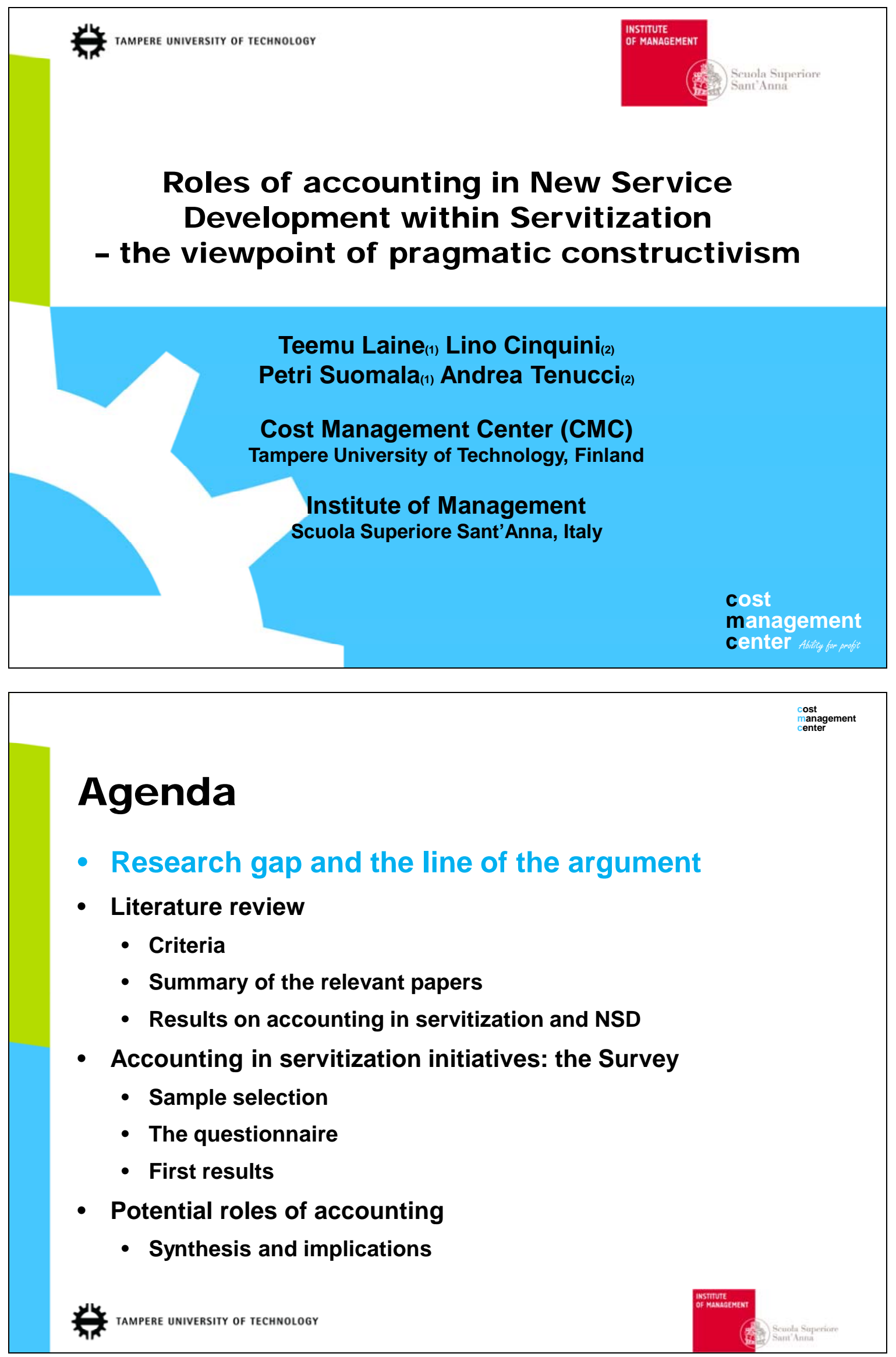




\section{Research gap}

\section{Accounting for supporting servitization}

- "The principal research need [in servitization] is to engineer tools or techniques that practitioners can apply to help in service design, organisational design and organisational transformation." (Baines et al. 2009)

$\rightarrow$ The potential roles of accounting for supporting servitization?

- Servitization with emphasis on offering development instead of relationship management (Oliva \& Kallenberg 2003, Penttinen \& Palmer 2007)

$\rightarrow$ The current and potential roles of accounting for NSD within servitization?

\section{Research gap}

\section{Pragmatic constructivism viewpoint}

- Servitization is a major organizational change (in offering and/or relationships)

$\rightarrow$ Pragmatic constructivism is a sound basis for analyzing socially constructed realities of many actors, or realities under construction

$\rightarrow$ It has been used in the context of accounting supporting strategic level organizational changes (Mitchell et al. 2013).

- New offering development requires ex ante accounting information about the future business impacts (Nixon 1998, Davila \& Wouters 2007)

$\rightarrow$ The concepts of fact, possibility, value and communication could help in outlining the potential roles of accounting in NSD within servitization 


\section{The line of the argument}

1. The knowledge gap of the supportive tools and techniques for servitization $\rightarrow$ roles of accounting in NSD

2. A literature review on the research gap and the roles of accounting in the new realities resulting from the servitization processes

3. Survey data is reflected upon the review results to better characterize the current servitization initiatives and current/potential accounting

4. Pragmatic constructivism is used as a framework to describe the requirements for and potential of accounting in servitization

5. Implications, an emphasis on in-depth case studies

TAMPERE UNIVERSITY OF TECHNOLOGY

\section{Agenda}

- Research gap and the line of the argument

- Literature review

- Criteria

- Summary of the relevant papers

- Results on accounting in servitization and NSD

- Accounting in servitization initiatives: the Survey

- Sample selection

- The questionnaire

- First results

- Potential roles of accounting

- Synthesis and implications 


\section{Literature Review}

\section{Rules and criteria}

\section{- Journal selection:}

- selected thirty-three (33) journals on servitization, accounting and control form ABS Journal Ranking:

- Accounting: 21 journals with 'grades 3-4 in ABS' and classified in the field of "Accounting";

- Service: 12 journals with 'service' in title.

- Time span: 1995-2013

\section{- Search criteria:}

- Criteria 1: keywords "accounting" OR "control" in abstracts AND "servitization" OR "servitisation" OR "new service development" in all fields.

- Criteria 2: keywords "servitisation" OR "servitization" in abstract.

\section{Literature Review}

\section{Service literature, 12 journals}

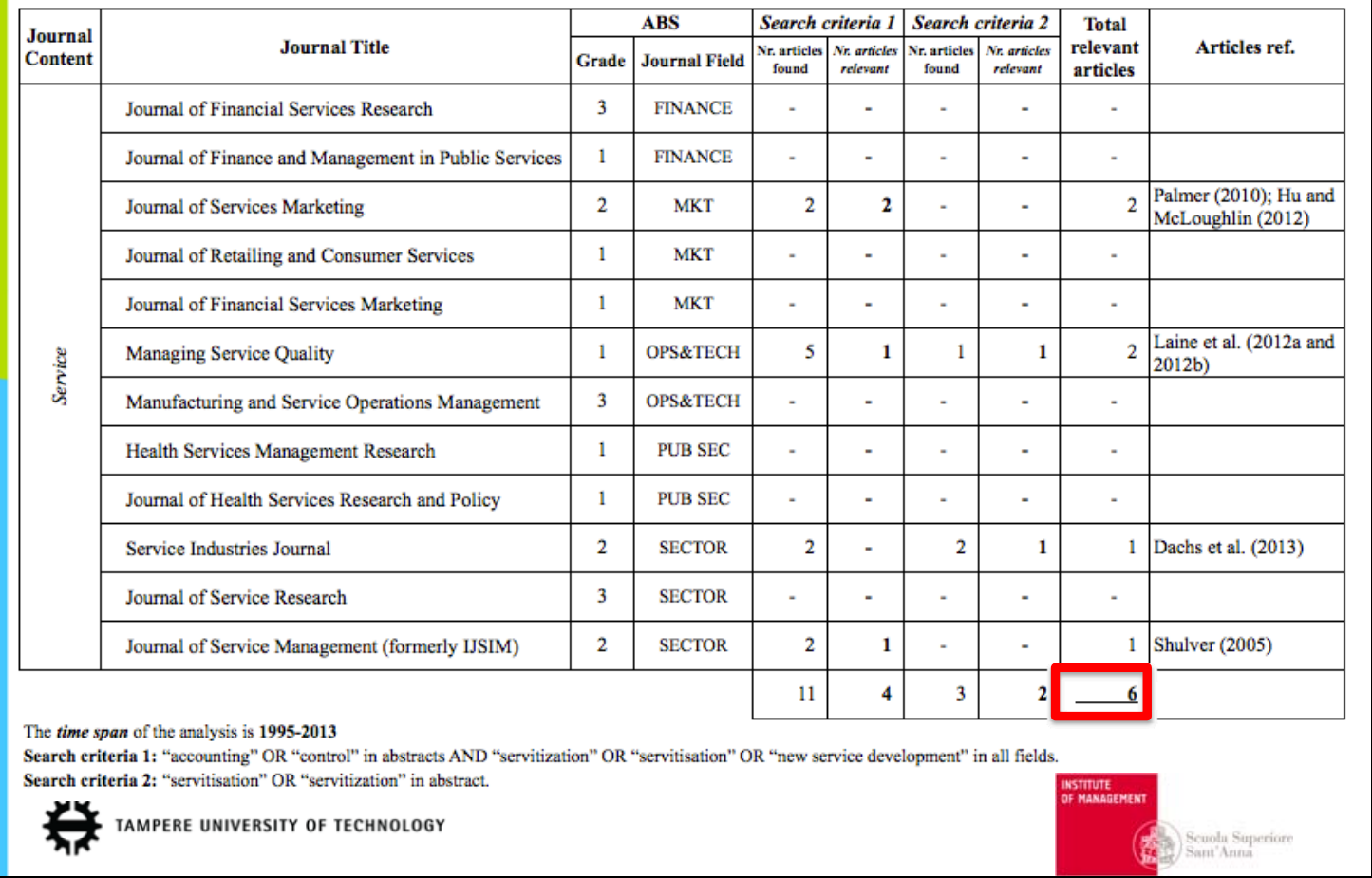




\section{Literature Review}

\section{Accounting literature, 21 journals}

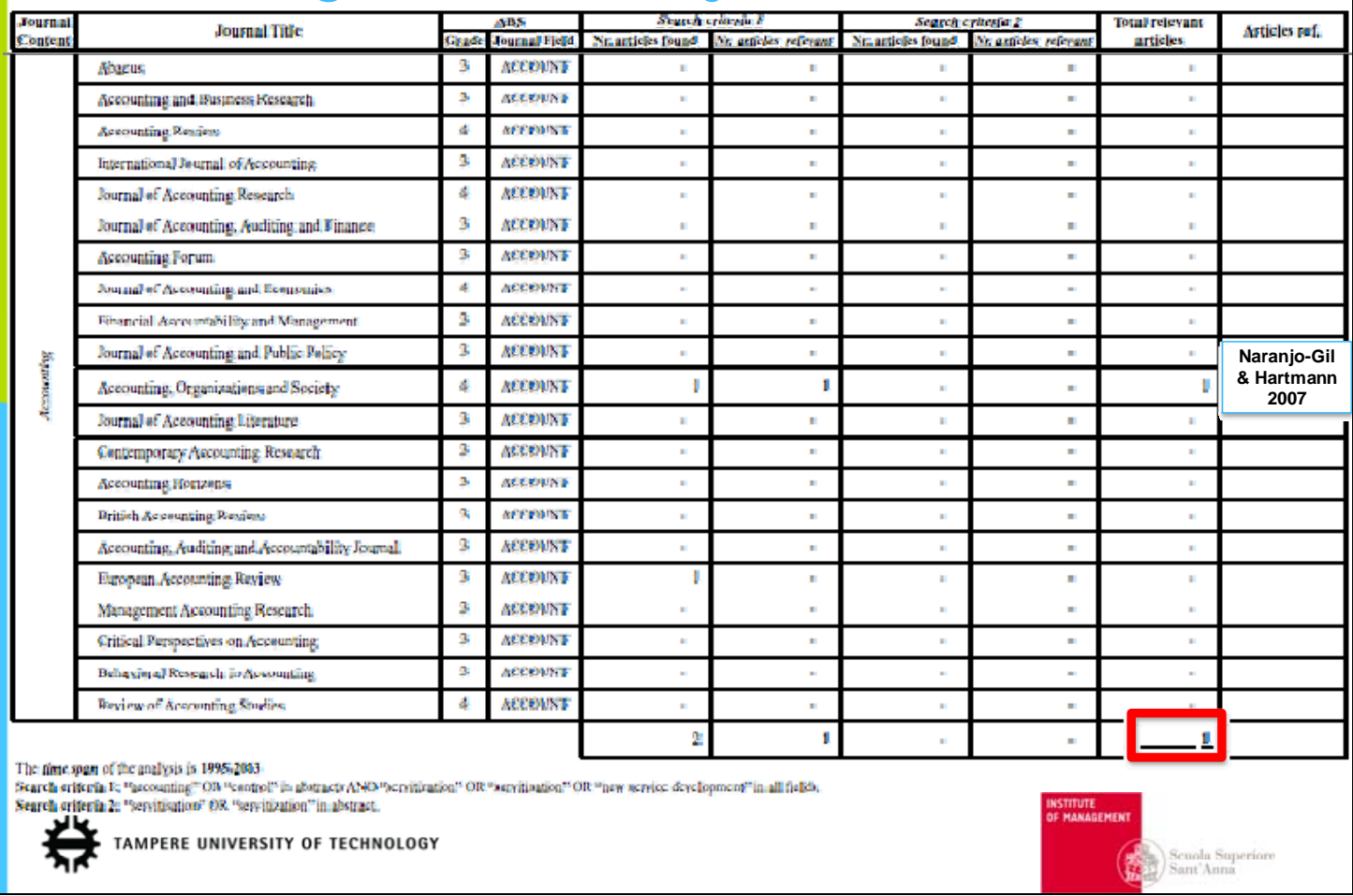

\section{Summary of the relevant papers}

\section{Why the papers are relevant}

\section{Article \\ Shulver (2005) - Operational loss and new service design}

Naranjo-Gil \& Hartmann (2007) MAS and strategic change

Palmer (2010) - Customer experience management: review

Hu \& McLaughlin (2012) - Creating new markets for industrial services

Laine et al. (2012a) - Management accounting roles in servitisation

Laine et al. (2012b) - Using a

business game concept in servitization

Dachs et al. (2013) - Servitisation in European manufacturing

\section{Content}

five service design cases ex post loss control via NSD

Survey in hospitals, how top management teams and MAS affect strategic changes

Assesses the concept of customer experience management

How the new markets are created for the new type of offerings

What roles MA takes in justifying, defining and controlling servitization

How a business game concept on customers' business is used to support servitization

Large scale database figures about servitization in different countries

\section{Relevant aspects}

NSD responds to problems in the existing system, measured as loss

Among the few examples on

accounting roles in strategic changes

It is difficult to set planning and control process for customer experience

The innovation takes places inside and outside the firm (and requires accounting and control respectively)

Accounting objects in service, roles of accounting in decision-making

A business game concept helps to define and gain a shared understanding about servitization

The service revenues, differences based on industries, firm sizes etc.

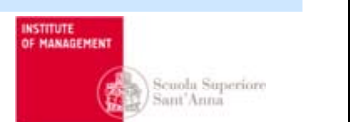




\section{Literature Review results}

\section{Accounting for servitization}

- Explicit studies on justifying, defining and controlling servitization rare:

- Control is important in strategy implementation (Naranjo-Gil \& Hartmann 2007)

- Different approaches to service: company, customer, product and process as different level accounting objects (Laine et al. 2012a)

- Different roles of accounting under different levels of uncertainty (roles identified by Burchell et al. 1980 as used in Laine et al. 2012a)

- A business game as a tool to increase customer awareness (Laine et al. 2012b)

- The overall gap was confirmed, no empirical evidence on using accounting from different actors' perspectives

- Laine et al. (2012b) described how a shared understanding about the possibilities and related values is built and communicated

\section{Literature Review results}

\section{Accounting and control for NSD}

- The usefulness of the NPD project models and related control:

- Adopting project models from NPD to service innovation

- Limitations in their adoption to understand operative aspects (Shulver 2005)

- For understanding the economic consequences of NSD:

- Service should be described and analyzed from multiple viewpoints

- Accounting could be connected to the analyses (Activity-Based Costing, ABC)

- Similarly to NPD accounting, the roles of accounting would change as the uncertainty is being reduced (Nixon 1998, as used in Laine et al. 2012a)

- Implications for managing NSD were brought up, but no evidence was provided or conceptual development presented regarding accounting for NSD 


\section{Agenda}

- Research gap and the line of the argument

- Literature review

- Criteria

- Summary of the relevant papers

- Results on accounting in servitization and NSD

- Accounting in servitization initiatives: the Survey

- Sample selection

- The questionnaire

- First results

- Potential roles of accounting

- Synthesis and implications

Therere university OF TECHNOLOGY

\section{Current roles of accounting: the survey}

\section{Sample selection and composition}

- Sample selection rules:

- Company located in Finland or Italy

- Machinery manufacturing sector

- Over 100 employees

- Final sample:

- Finland - 138 companies from:

- 126 direct email addresses (Finnish Federation of Technology Industries)

- 12 personal contacts

- Italy - $\mathbf{3 1 3}$ companies from:

- 283 info addresses (Amadeus database)

- 30 personal contacts

- Total: 451 companies

- Respondents:

- Financial managers, Service managers, R\&D managers 


\section{Current roles of accounting: the survey}

\section{The questionnaire}

- Online questionnaire - Webropol.com

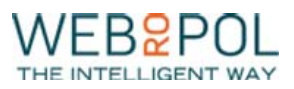

- Questionnaire structure:

- 4 Sections:

- I - Background of the company and the respondent

- II - Overview of the NSD \& NPD activities

- III - Accounting and control for NSD/NPD activities

- IV - Potential for developing accounting/control

- 26 questions

- Measurement scale:

- Yes/No

- Likert scale from 1 (i.e. "not at all") to 7 (i.e. "to a great extent")

TAMPERE UNIVERSITY OF TECHNOLOGY

\section{First results: Positioning NSD}

\section{$4 \%$ response rate}

- The importance of the service business:

- 5,3/7- significant overall importance of service business

- The share of service revenues $\sim 20-25 \%$ of total revenues

- The share of service in product offerings $\sim 40 \%$

$\rightarrow$ Mainly machinery manufacturers, with service as a strategic issue

- The organization and key actors of NSD:

- Service manager or R\&D manager are responsible for NSD

- Business controller is responsible for the financial control of NSD

- The share of NSD is only a small part of the total R\&D costs, especially in terms of costs (12\% of costs, $9 \%$ of resources)

- The share of the NSD projects is $13 \%$ of the project portfolio

$\rightarrow$ Developing new services remains actually less emphasized 


\section{First results: Acc./Control roles in NSD}

\section{$4 \%$ response rate}

- NPD projects are managed more or less systematically $(5,0)$, NSD projects are less systematically managed $(4,3)$

- Systematic NSD management is associated with systematic NPD, but also with the importance of the service products in offerings

- The number and use of accounting tools in NPD seem to vary, project costs, product costs and customer value the most often mentioned objects

$\rightarrow$ Accounting is most often used to provide facts about NPD project costs (much less about more informal NSD project)

- The priority $(4,1)$ and success rate $(4,1)$ equals between NPD and NSD, but how this priority is defined or the success measured?

- Most companies have just project budgets and product cost estimates

- Some estimate prices, some have cost targets, but no wide use of cost targets, cost estimates, volume estimates etc.

$\rightarrow$ How are the personnel responsible for NSD actually supported?

TAMPERE university OF TEChNology

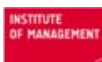

\section{First results: Developing Acc./control}

\section{$4 \%$ response rate}

- The overall ability of accounting and control (1-7):

- Neutral in supporting strategy $(4,6)$, worse in service strategy $(4,3)$

- At best in supporting product cost $(4,9)$ and profit calculations $(4,6)$

- The more important the service strategy is, the better accounting supports service activities (no significance yet)

- At worst in supporting creativity $(2,9)$ or managerial work in service $(3,9)$

$\rightarrow$ Lack of support for individual actors in NSD management?

- No significant changes in accounting and control for NPD/NSD (1-7):

- Overall change rate of NPD/NSD accounting is neutral $(3,2-3,9)$

- The changes in the financial control of the NPD/NSD are not necessarily in line with the strategic changes $(4,4)$, what they definitely should be

$\rightarrow$ The accounting systems are relatively static, the changes are not clearly based the current strategy or individual actors' needs 


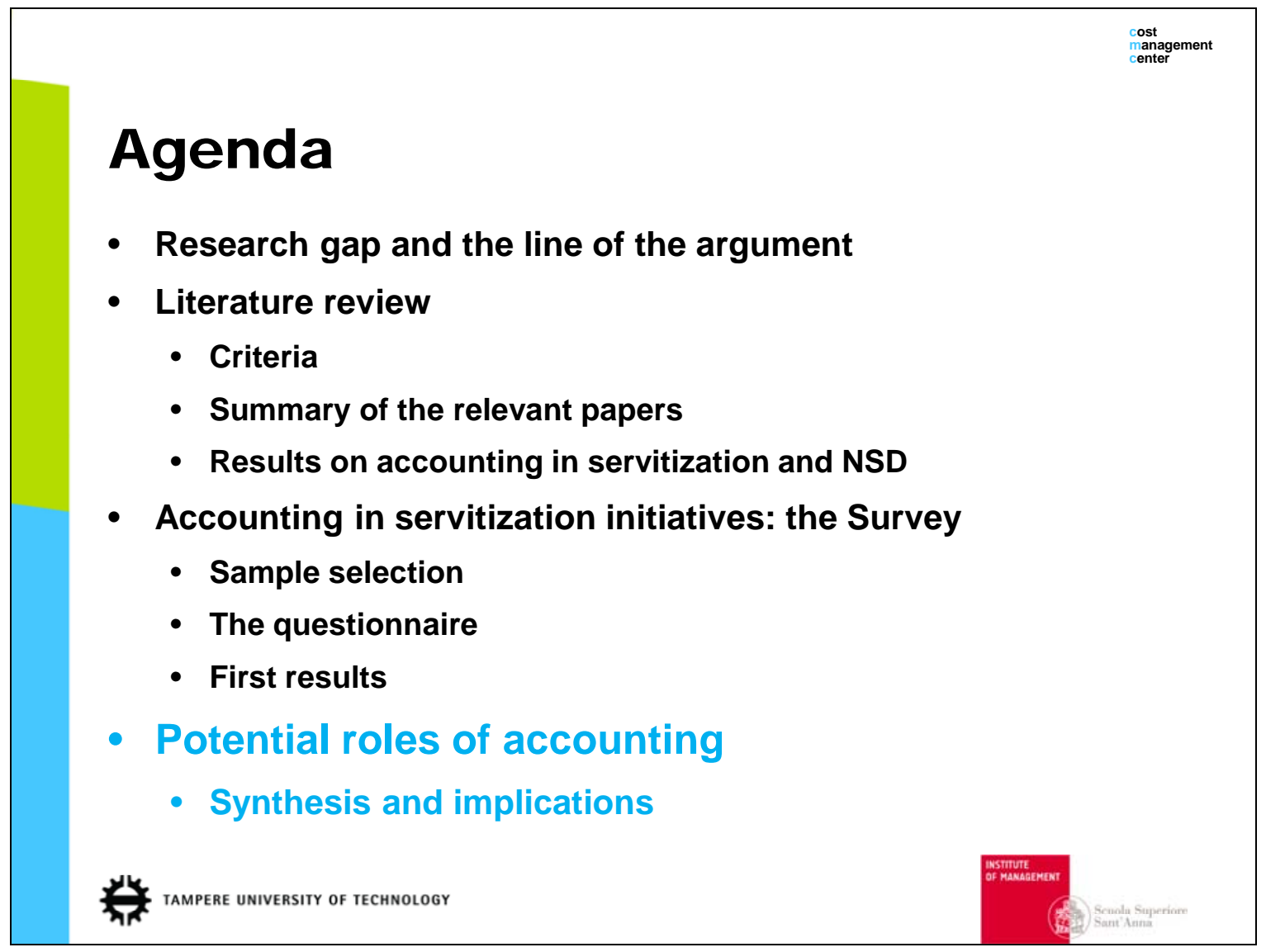

- Research gap and the line of the argument

Literature review

Criteria

- Sample selection

The questionnaire

First results

- Potential roles of accounting

- Synthesis and implications

TAMPERE UNIVERSIIY OF TeCHNOLOGY

\section{Potential roles of accounting}

\section{Synthesis of the findings}

- The gap was confirmed by the review and preliminary survey results:

- The servitization context sets new challenges for designing/using accounting

$\rightarrow$ The literature remains silent about the actual support from accounting for NSD

- Actor approach holds potential in fulfilling the gap:

- The main actors of servitization process vary, sometimes there are only a few NSD projects/resources and the NSD activities are less systematically managed

$\rightarrow$ The reality and its key actors in the servitizing companies should be clarified

- The key actors get support from accounting primarily regarding the project costs and product cost (accounting provides economic facts)

$\rightarrow$ How accounting could help in clarifying the individual actors realities and help their communication? Do the actors get the need they require? 


\section{Potential roles of accounting}

\section{Agenda for further research}

1. defining and positioning the servitization initiatives from multiple actors' perspectives to outline the requirements set for accounting,

2. examining the current and potential roles of accounting within servitization

3. focusing particularly on accounting development in this context.

- The agenda for further research holds potential regarding the roles of accounting in the strategic change context (Naranjo-Gil \& Hartmann 2007, Cinquini \& Tenucci 2010, Mitchell et al. 2013), where the realities of the key actors are significantly redefined.

- Next steps: survey in progress, conducting selected qualitative cases. 


\section{References}

Baines, T.S., Lightfoot, H.W., Benedettini, O., \& Kay, J.M. 2009. The servitisation of manufacturing: A review of literature and reflection on future challenges. Journal of Manufacturing Technology Management, 20(5), 547567.

Barontini R., Cinquini L., Giannetti R. and Tenucci A. 2013. Models of performance and value measurement in service systems, in Cinquini L., Di Minin A. and Varaldo R. (Eds.), New Business Models and Value Creation: A Service Science Perspective, Springer, Milano, 105-125.

Burchell, S., Clubb, C., Hopwood, A., Hughes, J., and Nahapiet, J. 1980. The roles of accounting in organizations and society, Accounting, Organizations and Society, 5(1), 5-27.

Cinquini, L., Tenucci, A. 2010. Strategic management accounting and business strategy: a loose coupling? Journal of Accounting \& Organizational Change, 6(2), 228-259.

Dachs, B., Biege, S., Borowiecki, M., Lay, G., Jäger, A., Schartinger, D. 2013. Servitisation in European manufacturing industries: empirical evidence from a large-scale database, The Service Industries Journal.

Davila, T., Wouters, M. 2007. Management accounting in the manufacturing sector: managing costs at the design and production stages, in: Chapman, C.S., Hopwood A.G., \& Shields, M. (Eds.), Handbook of Management Accounting Research. Elsevier, Amsterdam, the Netherlands, 831-858.

Hu, Y., McLoughlin, D. 2012. Creating new market for industrial services in nascent fields, Journal of Services Marketing, 26(5), 322-331.

Laine, T., Paranko, J., Suomala, P. 2012a. ”Management accounting roles in supporting servitisation: Implications for decision-making at multiple levels”, Managing Service Quality, 22(3), 212-232.

Laine, T., Paranko, J., Suomala, P. 2012b. Using a business game concept to enhance servitization: a longitudinal case study, Managing Service Quality, 22(5), 428-446.

Mitchell, F. Nielsen, L. B., Nørreklit, H., Nørreklit, L. 2013. Scoring strategic performance: a pragmatic constructivist approach to strategic performance measurement. Journal of Management and Governance, 17, 5-34

Naranjo-Gil, D., Hartmann, F. 2007. Management accounting systems, top management team heterogeneity and strategic change, Accounting, Organizations and Society, 32(7-8), 735-756.

Nixon, B. 1998. Research and development performance measurement: a case study, Management Accounting Research, 9, 329-355.

Nørreklit, H., Nørreklit, L., Mitchell, F. 2010. Towards a paradigmatic foundation for accounting practice. Accounting, Auditing \& Accountability Journal, 23, 733-758.

Oliva, R., Kallenberg, R. 2003. Managing the transition from products to services, International Journal of Service Industry Management, 14, 160-172.

Palmer, A. 2010. Customer experience management: a critical review of an emerging idea, Journal of Services Marketing, 24(3), 196-208.

Penttinen, E., Palmer, J. 2007. Improving firm positioning through enhanced offerings and buyer-seller relationships, Industrial Marketing Management, 36(5), 552-64.

Shulver, M. 2005. Operational loss and new service design, International Journal of Service Industry Management, 16(5), 455-479. 